\title{
Bizantyńscy intelektualiści o wojnie i pokoju (Mikołaj Mistyk i Teodor Dafnopates)
}

Celem niniejszego tekstu jest przeanalizowanie podejścia do kwestii wojny i pokoju ${ }^{2}$ dwóch bizantyńskich intelektualistów, a mianowicie Mikołaja Mistyka, dwukrotnego patriarchy Konstantynopola (901-907, 912-925), i Teodora Dafnopatesa, sekretarza cesarza Romana Lekapena, na podstawie ich listów powstałych w związku z bizantyńsko-bułgarskim konfliktem zbrojnym z lat $912-927^{3}$. Choć nie mamy w tym przypadku do czynienia z teoretycznymi rozważaniami o wojnie i pokoju, a tekstami powstałymi w czasie wojny, w których ta kwestia była narzędziem prowadze-

\footnotetext{
1 Prof. dr hab. Mirosław J. Leszka, profesor w Katedrze Historii Bizancjum na Wydziale Filozoficzno-Historycznym Uniwersytetu Łódzkiego; email: miroslaw.leszka@uni.lodz.pl; ORCID: 0000-0003-2643-4520.

2 O poglądach Bizantyńczyków na kwestię wojny i pokoju, patrz: S.N. Malakhov, Koncepcija mira v politicheskojj ideologii Vizantii pervojj poloviny X v. Nikolaj Mistik Feodor Dafnopat, „Antichnaja Drevnost i Srednie Veka” 27 (1995) s. 19-31; Peace and Warin Byzantium. Essays in Honor of George T. Dennis, S.J., ed. T.S. Miller - J. Nesbit, Washington 1995; J. Haldon, Warfare, State and Society in the Byzantine World, London 1999, s. 13-33; J. Chrysostomides, Byzantine Concepts of War and Peace, w: War, Peace and World Orders in European History, red. A.V. Hartmann - B. Heuser, London - New York 2001, s. 91-101; P.M. Strässle, Krieg und Frieden in Byzanz, „Byzantion” 74 (2004) s. 110-129; K.R. Kapsalykova, Predstavlenie o vojjne $i$ armii v Vizantii (seredina $I X-s e-$ redina XI), Ekaterinoburg 2017 (niepublikowana praca doktorska); K. Marinow, Wojna i pokój w Domu Bożym. Uwagi na temat ideologicznej wymowy dwóch motywów w mowie Na pokój z Bułgarami, w: Piotr I Święty, car bułgarski (ok. 912-969). Maria Lekapena, caryca butgarska (ok. 912-?963), red. Z.A. Brzozowska - M.J. Leszka - K. Marinow, Kraków 2018, s. 219-244.

3 Na temat tego konfliktu: M.J. Leszka, Symeon I Wielki a Bizancjum. Z dziejów stosunków bułgarsko-bizantyńskich $w$ latach 893-927, Byzantina Lodziensia 15, Łódź 2013, s. 117-233 (tam dalsza literatura).
} 
nia pokojowych negocjacji, to dają one dobre wyobrażenie o bizantyńskim sposobie postrzegania wojny i pokoju w pierwszych dekadach X wieku.

Mikołaj Mistyk ${ }^{4}$, autor pierwszego korpusu listów, który znajdzie się w obrębie mojej analizy, urodził się w 852 roku w Konstantynopolu. Należał do kręgu uczniów patriarchy Focjusza. Jego kariera miała początkowo charakter świecki. Z tego okresu wywodzi się przydomek „Mistyk”, czyli urzędnik zajmujący się sprawami tajnymi. Jednak do historii Mikołaj przeszedł jako patriarcha Konstantynopola. Był nim dwukrotnie. Najpierw w latach 901-9075 , a później od $912^{6}$ aż do śmierci w 925 roku. Listy do Symeona (zachowało się ich dwadzieścia sześć) 7 powstały w okresie powtórnego spra-

4 Na temat Mikołaja Mistyka i jego twórczości, patrz m.in. R.J.H. Jenkins, A Note on the Patriarch Nicholas Mysticus, w: Studies on Byzantine History of the $9^{\text {th }}$ and $10^{\text {th }}$ Centuries, red. R.J.H. Jenkins, London 1970, s. 145-147; V. Stanković, Carigradski patrijarsi i carevi makedonske dinastije, Beograd 2003, s. 87-112; J.N. Ljubarskijj, Zamechanija o Nikolae Mistike v svjazi s izdaniem ego sochinenijj, w: Vizantijjskie istoriki i pisateli (sbornik statejj), red. J.N. Ljubarskijj, Sankt-Peterburg 1999, s. 55-67; M.J. Leszka, Mikołaj Mistyk, patriarcha Konstantynopola $w$ świetle korespondencji z Symeonem, władca Bułgarii, „Balcanica Posnaniensia” 18 (2011) s. 23-33. Kwestia stosunku Mikołaja Mistyka do wojny znajdowała się już w obrębie moich rozważań: M.J. Leszka, Obraz wojny w Listach Mikołaja Mistyka do Symeona, władcy butgarskiego, „Slavia Antiqua” 47 (2006) s. 9-16. W niniejszym tekście poglądy Mikołaja Mistyka zostały skonfrontowane z poglądami Teodora Dafnopatesa.

5 Utrata patriarszego tronu była następstwem nieustępliwej postawy Mikołaja wobec czwartego małżeństwa Leona VI. O roli Mikołaja w sporze o tetragamię: P. KarlinHayter, Le synode à Constantinople de 886 à 912 et le rôle de Nicolas le Mystique dans l'affaire de la tétragamie, JÖB 19 (1970) s. 59-101; S. Tougher, The Reign of Leo VI (886-912). Politics and People, Leiden - New York - Köln 1997, s. 156-161; G. Dagron, Kościót i państwo (połowa IX-koniec X wieku), w: Historia chrześcijaństwa. Religia. Kultura. Polityka, t. 4: Biskupi, mnisi i cesarze 610-1054, tł. M. Żurowska et al., red. G. Dagron - P. Riché - A. Vauchez, Warszawa 1999, s. 163-169.

6 Nie są znane okoliczności ani dokładna data powrotu Mikołaja na stanowisko patriarchy. Wydaje się jednak, że istnieją przesłanki do uznania, iż stało się to jeszcze za życia Leona VI. Świadczyłoby o tym to, iż doszło między nim a cesarzem do porozumienia. Zob. I. Bozhilov, Car Simeon Veliki: zlatnijat vek na Srednovekovna Bylgarija, Sofija 1983, s. 102; Dagron, Kościół, s. 166.

7 W tzw. bułgarskim dossier Mikołaja Mistyka znajdują się listy do Symeon (Nicolaus I Constantinopolitanus patriarcha, Epistula 3, maj 912/lipiec 913; 5, pocz. lipca 913; 6, lipiec/ sierpień 913; 7, lipiec/sierpień 913; 8, lato/jesień 914; 9, koniec sierpnia/początek września 917; 10, początki 918; 11, zima 918/919; 14, między 9 lipca a początkiem sierpnia 920; 15, sierpień/wrzesień 920; 16, po 17 grudnia 920 a przed lutym 921; 17, luty 921(?); 18, wiosna/ lato $921 ; 19$, wiosna/lato 921; 20, lato 921; 21, między latem 921 a końcem 922; 22, między latem 921 a końcem 922); 23, 922; 24, 922/czerwiec 923; 25, 922/czerwiec 923; 26, 922/ czerwiec $923 ; 27,922$ /czerwiec 923; 28, czerwiec 922/czerwiec 923; 29, 923/924; 30, tuż po 
wowania przez Mikołaja godności patriarszej w toku rozwijającego się konfliktu bizantyńsko-bułgarskiego. W początkach tego okresu (maj/czerwiec 913-luty 914 roku) Mikołaj stał na czele rady regencyjnej rządzącej w imieniu małoletniego Konstantyna VII (tę funkcję pełnił jeszcze przez krótki czas pod koniec 918 i w początkach 919 roku wraz z magistrem Stefanem). To on był wtedy odpowiedzialny za sposób rozwiązania pierwszej fazy konfliktu bizantyńsko-bułgarskiego i wydaje się, iż jego późniejsze listy do Symeona były z jednej strony inspirowane poczuciem współodpowiedzialności, jako głowy Kościoła konstantynopolitańskiego, za losy państwa, z drugiej zaś czysto osobistą potrzebą sfinalizowania sprawy, którą próbował rozwiązać w czasach, gdy pełnił funkcję regenta Konstantyna VII ${ }^{8}$.

Drugi zespół listów skierowanych do Symeona sygnowany jest przez cesarza Romana Lekapena i składa się z trzech pism9. Jak się powszechnie sądzi, ich autorem nie był sam cesarz, ale Teodor Dafnopates pełniący wówczas funkcję cesarskiego sekretarza ${ }^{10}$. Teodor urodził się w ostatniej dekadzie IX wieku. Był z pochodzenia być może Armeńczykiem. W swojej karierze, która uchwytna jest w źródłach od początku lat dwudziestych, a kończy się

listopadzie 924; 31, styczeń/kwiecień 925), jak również do arcybiskupa Bułgarii (4, maj 912/ lipiec 913; 12, zima 918/919) oraz do ,pierwszego człowieka Symeona” - 13, zima 918/919. Chronologia listów za wydaniem Jenkinsa - Westerinka (z korektą przy liście 8).

8 Na temat charakteru relacji między Mikołajem Mistykiem i Symeonem, patrz Leszka, Mikołaj Mistyk, s. 23-33 (tam dalsza literatura).

9 Kopie listów pochodzące $\mathrm{z}$ drugiej połowy X wieku zostały znalezione w drugiej połowie XIX wieku w bibliotece monastyru św. Jan na Patmos.

10 Na temat życia i twórczości Teodora: M. Sjuzjumov, Ob istoricheskom trude Feodora Dafnopata, „Vizantijjskoe obozrenijje” 2 (1916) s. 295-302; A. Kazhdan, Daphnopates, Theodore, w: The Oxford Dictionary of Byzantium, ed. A. Kazhdan, New York - Oxford 1991, s. 588; A. Kazhdan, A History of Byzantine Literature (850-1000), ed. A.C. Angelidi, Athens 2006, s. 152-157; T. Antonopoulou, A Textual Source and Its Implications: On Theodore Daphnopates' Sermon On the Birth of John the Baptist, „Byzantion” 81 (2011) s. 9-17; D. Chernoglazov, Beobachtungen zu den Briefen des Theodoros Daphnopates. Neue Tendenzen in der byzantinischen Literatur des zehnten Jahrhunderts, ByZ 106 (2013) s. 623-644; A.S. Mokhov - K.R. Kapsalykova, Obrazy vojjny v vizantijjskojj istoricheskoj literature Xv.: Feodor Dafnopat, „Nauchnye vedomosti Belgorodskogo gosudarstennogo universiteta. Serija Istorija. Politologija” 36 (2015) s. 44-49; Kapsalykova, Predstavlenie, s. 151-155. Argumenty świadczące o Teodorze Dafnopatesie jako autorze listów Romana Lekapena do Symeona podaje: E. Aleksandrov, Diplomaticheskaja perepiska carja Simeona s imperatorom Romanom Lakapinom, „Palaeobulgarica” 14/2 (1990) s. 16-17). Tu również analiza okoliczności powstania listów. Zobacz także: V.N. Zlatarski, Pismata na vizantijjski imperator Romana Lakapena do bygarskija car Simeon, ,Sbornik narodni umotvorenija, nauka i knizhnina" 13 (1896) s. 282-322. 
po śmierci Romana II (959-963), pełnił urząd cesarskiego sekretarza, logotety toustratiotikou, prefekta Konstantynopola, otrzymał także tytuł magistra (za Romana II). Był dostojnikiem państwowym, ale i człowiekiem pióra. Oprócz listów (zachowało się 40) pisał dzieła o charakterze hagiograficznym, mowy (pogrzebowa dla Romana II, przypisuje się mu niekiedy mowę $N a$ pokój z Bułgarami). Niektórzy uczeni uważają, że był autorem VI księgi Kontynuacji Teofanesa. Trzy analizowane w artykule listy powstały po spotkaniu Romana Lekapena z Symeonem I, władcą Bułgarii, które prawdopodobnie odbyło się późną jesienią 923 roku $^{11}$. Niestety, podobnie jak w przypadku korespondencji Mikołaja Mistyka nie zachowały się listy bułgarskiego władcy do cesarza.

\section{Przyczyny wojny}

Dla Mikołaj Mistyka wojna była złem ${ }^{12}$, podobnie zresztą jak i dla Teodora Dafnopatesa ${ }^{13}$, za którą, z oczywistych względów, odpowiedzial-

$11 \mathrm{Na}$ temat kontrowersji wokół datowania spotkania Symeona z Romanem Lekapenem, zob. Leszka, Symeon I Wielki, s. 206. Ze względu na nawiązania do spotkania dwóch władców listy te w zależności od przyjętej daty tego wydarzenia (na 923 lub 924 rok) datuje się na rok 924 albo 925 rok. Analizowane poniżej listy Romana noszą w wydaniu Westerinka - Darrouzèsa numery 5, 6, 7, co ma odzwierciedlać kolejność ich napisania. Jakiś czasem temu James Howard-Johnston przedstawił propozycję nieco innej ich sekwencji. Jego zdaniem list 7 (według numeracji Westerinka - Darrouzèsa) rozpoczynał korespondencję, a nie ją kończył. Takie usytuowanie wzmiankowanego listu lepiej oddaje zdaniem angielskiego uczonego zmiany zachodzące we wzajemnych relacjach między Symeonem i Romanem. Zob. J. Howard-Johnston, A short piece of narrative history: war and diplomacy in the Balkans, winter 921/2-spring 924, w: Byzantine Style, Religion and Civilization. In Honour of Sir Steven Runciman, ed. E. Jeffreys, Cambridge 2006, s. 353. Ze względu na to, że dla niniejszych rozważań kwestia ta nie ma specjalnego znaczenia, zachowuję numerację Westerinka - Darrouzèsa.

12 Szczególnie negatywnie oceniał patriarcha wojnę wydaną słabszemu przeciwnikowi. Biskup Konstantynopola odwoływał się do konkretnej sytuacji. Tak postrzegał wystąpienie Symeona przeciw Bizancjum rządzonemu przez małoletniego cesarza Konstantyna VII. Zob. Nicolaus I Constantinopolitanus patriarcha, Epistula 5. Na tym samym poziomie negacji stawia również wojnę, która została rozpoczęta bez powodu, bez jakiejkolwiek winy strony, która stała się przedmiotem ataku. Zob. Nicolaus I Constantinopolitanus patriarcha, Epistula 5. To też jest wyraźna aluzja do konfliktu bułgarsko-bizantyńskiego. List 5, z którego pochodzi ta opinia, powstał zapewne w 913 rok jeszcze przed spotkaniem Mikołaja i Symeona. Jak można sądzić, patriarcha wskazywał w ten sposób, iż nie ma żadnych powodów, które usprawiedliwiałyby wystąpienie bułgarskiego władcy przeciw Bizancjum.

13 Np. Theodorus Daphnopates, Epistula 7; Mokhov - Kapsalykova, Obrazy, s. 47-48. 
ny był $\operatorname{szatan}^{14}$. Co miało nim kierować przy rozpętaniu wojny między Bułgarią i Bizancjum? Szatan, zdaniem patriarchy Konstantynopola, chciał ukarać Bułgarów za to, że przeszli na chrześcijaństwo. Chciał doprowadzić do zniszczenia jedności i zgody, jakie zapanowały między chrześcijańską Bułgarią a Bizancjum, od którego ta pierwsza przyjęła nową wiarę i dzięki temu uwolniona została spod jego władzy. Jedność w wierze przekreśliła dawne konflikty, a między Bułgarami i Bizantyńczykami zapanował pokój ${ }^{15}$. Szatan do swego celu wykorzystał złych ludzi, „służących jego występkom", i ludzi słabych, którzy nie potrafili wytrwać przy dobru. Tacy ludzie znajdowali się zarówno po stronie bizantyńskiej, jak i bułgarskiej ${ }^{16}$. Jedni i drudzy naruszyli układy pokojowe i doprowadzili do rozlewu krwi. Tych, którzy przyczynili się do rozpętania wojny, stołeczny patriarcha nazywa przestępcami ${ }^{17}$. Co nimi kieruje? Dążność do przywłaszczania cudzych rzeczy ${ }^{18}$ i do wtrącania się w sprawy drugiego państwa ${ }^{19}$. Jaką rolę w kontekście rozpętania wojny przypisywał stołeczny patriarcha bułgarskiemu władcy? Patriarcha z oczywistych względów daleki był od wyartykułowania jednoznacznego poglądu w tej kwestii. Jego listy pełniły rolę narzędzia oddziaływania na Symeona. W zależności od stanu stosunków bizantyńsko-bułgarskich w momencie, w którym pisany był dany list, patriarcha $\mathrm{w}$ różny sposób określał rolę bułgarskiego władcy. Z jednej strony wskazywał na brak jego odpowiedzialności za wywołanie zbrojnego konfliktu, twierdząc, że za wojną stoi zły duch i źli dostojnicy państwowi, a sam władca jest rozumny i dobry. Z drugiej zaś strony bardzo wyraźnie

14 Np. Nicolaus I Constantinopolitanus patriarcha, Epistula12, s. 86 (do arcybiskupa Bułgarii); 20, s. 132; 21, s. 142; Theodorus Daphnopates, Epistula 4, s. 55; por. Mokhov - Kapsalykova, Obrazy, s. 48.

15 Ta myśl wielokrotnie pojawia się w listach Mikołaja Mistyka $(8 ; 9 ; 10 ; 12 ; 21)$. Z perspektywy Konstantynopola wspólna wiara łącząca Bułgarię i Cesarstwo wytworzyła między nimi szczególne stosunki. Szerzej na ten temat w: D. Angelov, Metody vizantijjskoj diplomatii $v$ otnoshenijakh s Bolgariejj po danym pisem konstantinopolskogo patiarkha Nikolaja Mistika, ,Voprosy Istorii Slavjan” 1 (1963) s. 63-65; F.E. Wozniak, The Metaphysics of Byzantine Diplomacy in the Relations of the Byzantines and Bulgarians 880's - 920’s, GOTR 21 (1976) s. 289-297. W listach wyraźnie widoczna jest myśl, że Bułgarzy, podejmując działania zbrojne przeciw Bizantyńczykom, występowali przeciw tym, którym zawdzięczali przyjęcie chrześcijaństwa, przeciwko swym duchowym nauczycielom i ojcom.

16 Nicolaus I Constantinopolitanus patriarcha, Epistula 9.

17 Nicolaus I Constantinopolitanus patriarcha, Epistula 17.

18 Nicolaus I Constantinopolitanus patriarcha, Epistula 21.

19 Nicolaus I Constantinopolitanus patriarcha, Epistula 5. 
mówił o odpowiedzialności Symeona za kontynuowanie wojny. Motywem pchającym go do wojny miała być dążność do panowania nad cesarstwem bizantyńskim ${ }^{20}$. Im bliżej 925 roku, tym ten pogląd staje się coraz bardziej dominujący, co z pewnością było następstwem coraz większego pesymizmu ogarniającego stołecznego biskupa, co do skuteczności swego oddziaływania na Symeona.

W odróżnieniu od Mikołaja Mistyka Teodor Dafnopates, piszący w imieniu cesarza Romana Lekapena, całą odpowiedzialnością za wybuch wojny między Bizancjum i Bułgarią obarczał Symeona. Bizantyński autor kładzie nacisk na to, że powodem wojny było dążenie Symeona do nazywania siebie cesarzem Romajów i panowania nad ich ziemiami. Oskarża go o to, że ziemie te - choć nie ma do nich żadnego prawa, ponieważ z woli Boga należały one do Romajów - chce zdobyć rozlewem krwi, przemocą. Symeon jest w oczach Dafnopatesa grabieżcą i zbrodniarzem, który złamał wcześniejsze porozumienia ${ }^{21}$.

Mikołaj Mistyk uważał, że za wszelką cenę trzeba dążyć do uniknięcia wojny. W tym celu należy trzymać się litery funkcjonujących układów pokojowych, a wszystkie sporne kwestie rozwiązywać w ramach negocjacji dyplomatycznych ${ }^{22}$. Patriarcha ostrzegał tych, którzy prą do wojny, że jej losy są zależne jedynie od woli Boga, a jej wynik zawsze pozostaje niewiadomy, bez względu na ludzkie wysiłki ${ }^{23}$. Nie ma żadnej gwarancji, że najlepsze przygotowania i zaangażowanie największych nawet sił doprowadzi do sukcesu.

$\mathrm{Z}$ analizy listów Mikołaja Mistyka wynika, że są jednak sytuacje, gdy działań wojennych nie można uniknąć, choć nawet wtedy trzeba być gotowym do zaniechania walki i podjęcia negocjacji pokojowych. Najogólniej rzecz ujmując, tym, co usprawiedliwia podjęcie działań zbrojnych, jest reakcja na czyjąś agresję. Patriarcha pisze, że usprawiedliwione jest wkroczenie na tereny przeciwnika, o ile on uczynił to wcześniej w stosunku do naszego terytorium ${ }^{24}$. Należy prowadzić działania wojenne, jeśli wróg zagraża naszej suwerenności, nie zadowalając się ustępstwami z naszej

20 Nicolaus I Constantinopolitanus patriarcha, Epistula 5; 18; 19; 21; 25; 27. Por. Wozniak, The Metaphysics, s. 292-293, 295.

21 Taki jest generalny wydźwięk listów Teodora Dafnopatesa, może z drobnym odstępstwem w liście 7, w którym pisze o jakichś innych osobach, które ,stały u początków tej wojny i słusznie zostały zgładzone", tł. A. Brzóstkowska, s. 175.

22 Nicolaus I Constantinopolitanus patriarcha, Epistula 5.

23 Nicolaus I Constantinopolitanus patriarcha, Epistula 10; 16; 17.

24 Nicolaus I Constantinopolitanus patriarcha, Epistula 9. 
strony $^{25}$. Z powyższego wynika, iż patriarcha usprawiedliwia prowadzenie wojny obronnej. Stołeczny biskup akceptował również, jak można sądzić, prowadzenie działań o charakterze prewencyjnym. Świadczy o tym list 9, w którym biskup przedstawia uzasadnienie zmobilizowania przez Bizantyńczyków znacznych sił i skierowania ich przeciw Bułgarom, ale nie po to, by z nimi walczyć, lecz by zastraszyć ich i wymusić zaniechanie wrogich Bizancjum działań zbrojnych ${ }^{26}$. Powyższe uwagi dotyczą przede wszystkim wojny między chrześcijanami. Patriarcha, jak można sądzić z fragmentu listu 21, nie miał takich obiekcji, jeśli chodzi o prowadzenie wojen z poganami ${ }^{27}$.

\section{Obraz wojny}

Mikołaj Mistyk, a także, choć w skromniejszy sposób, Teodor Dafnopates używali w swoich listach czegoś, co można by nazwać „obrazem wojny" 28 po to, aby przy jego pomocy trafić do sumienia bułgarskiego władcy i nakłonić go do zawarcia pokoju. Ten obraz jest ascetyczny i schematyczny, ale mimo to nośny i można w nim dostrzec pewne wątki, które mimo swej z pozoru uniwersalności zostały przywołane prawdopodobnie tylko dlatego, iż mogły one silniej wpłynąć na Symeona. Tym, co Mikołajowi Mistykowi szczególnie mocno wiąże się z wojną, to przelew $\mathrm{krwi}^{29}$. Ten wątek najczęściej występuje w analizowanych listach. Szczególnie dotyka Mikołaja, jak również Teodora Dafnopatesa fakt, że jest to przelew chrześcijańskiej, braterskiej krwi ${ }^{30}$. W jego konsekwencji pojawia się zjawisko wdowieństwa, sieroctwa, bezdzietności i wyludnienia $\mathrm{kraju}^{31}$. W czasie wojny giną krewni, najbliżsi przyjaciele, i to nie tylko zwykłych jej uczestników, ale również samych panujących ${ }^{32}$. To

25 Szerzej na ten temat poniżej.

26 Nicolaus I Constantinopolitanus patriarcha, Epistula 9.

27 Nicolaus I Constantinopolitanus patriarcha, Epistula 21.

28 Por. uwagi poczynione przez: Malakhov, Koncepcija, s. 22-23. Por. Marinow, Wojna i pokój, s. 221-235.

29 Na przykład występuje on w listach 9; 11; 13 (do pierwszego człowieka Symeona); $14 ; 16 ; 21$.

30 Nicolaus I Constantinopolitanus patriarcha, Epistula 11; 17; Theodorus Daphnopates, Epistula 5; 7.

31 Nicolaus I Constantinopolitanus patriarcha, Epistula 11; 23; 28.

32 Nicolaus I Constantinopolitanus patriarcha, Epistula 31. 
niesie z kolei za sobą żal, smutek, łzy33. Wojna jest źródłem okrucieństwa i cierpień ${ }^{34}$. Obok strat w ludziach konsekwencją zmagań zbrojnych są zniszczenia, spustoszenie terenów jednego i drugiego państwa ${ }^{35}$. Wizerunek ten dopełniają grabieże i pożary ${ }^{36}$. Na obraz wojny składa się również zjawisko niewoli ${ }^{37}$. Mikołaj Mistyk sugeruje, że nie można pozbawiać człowieka wolności i przetrzymywać jeńców ${ }^{38}$. Ten ledwie naszkicowany przy pomocy wzmiankowanych powyżej elementów obraz wojny wzmacnia jeszcze jeden szczególnie ważny dla patriarchy wątek. Jest nim los tych, którzy służą Bogu, i miejsc, gdzie ta służba się odbywa. Kilkakrotnie w swoich listach patriarcha pisze o niszczeniu kościołów i klasztorów męskich oraz żeńskich ${ }^{39}$. Wątek niszczenia kościołów i mordowaniu mnichów i kapłanów znajdujemy również w listach Romana Lekapena/Teodora Dafnopatesa ${ }^{40}$. Mikołaj Mistyk przywołuje także obraz hańbionych dziewic, które swoje życie poświęciły Bogu ${ }^{41}$, oraz mnichów, którym odebrano cześćc ${ }^{22}$. Wspomina kapłanów, którzy stali się obiektem zniewag oraz pogardy i którym uniemożliwiono wypełnianie ich powinności ${ }^{43}$. Ten wątek oczywiście nie dziwi, jeśli pamiętamy, że wyszedł on spod pióra człowieka Kościoła, dla którego los duchownych i świątyń musiał być szczególnie ważny. Jeśli do tego dodamy, że wojnę prowadziły w tym przypadku państwa chrześcijańskie, to fakt zwrócenia uwagi na ten aspekt działań wojennych przez patriarchę Konstantynopola, jak i Teodora Dafnopatesa jest całkowicie zrozumiały. Jest jednak jeszcze jeden powód, jak się wydaje, który decydował o tym, że Mikołaj Mistyk taki szczególny nacisk położył na nieszczęścia, które dotykały w czasie wojny mnichów. Była to próba odwołania się do osobistych doświadczeń Symeona, który w czasie swojego pobytu w Konstantynopolu został mnichem, a po powrocie do ojczystego kraju wiódł mnisze życie aż do chwili

33 Nicolaus I Constantinopolitanus patriarcha, Epistula 31; 17.

34 Nicolaus I Constantinopolitanus patriarcha, Epistula 11; 13; 14; 28.

35 Nicolaus I Constantinopolitanus patriarcha, Epistula 14; 23.

36 Nicolaus I Constantinopolitanus patriarcha, Epistula 9; 10; 28.

37 Nicolaus I Constantinopolitanus patriarcha, Epistula 20; 21; 28. Por. Theodorus Daphnopates, Epistula 5.

38 Nicolaus I Constantinopolitanus patriarcha, Epistula 21.

39 Nicolaus I Constantinopolitanus patriarcha, Epistula 14; 26; 28; 29.

40 Theodorus Daphnopates, Epistula 5.

41 Nicolaus I Constantinopolitanus patriarcha, Epistula 24; 28; 29.

42 Nicolaus I Constantinopolitanus patriarcha, Epistula 24; 29.

43 Nicolaus I Constantinopolitanus patriarcha, Epistula 29. 
przejęcia władzy w 893 roku $^{44}$. Ten domysł potwierdza list 14, w którym najpierw patriarcha czyni aluzje do ascetycznego trybu życia Symeona ${ }^{45}$, co z pewnością było konsekwencją monastycznego etapu w jego biografii, a następnie wzmiankuje cierpienia mniszek i mnichów, które przynosi im prowadzona przez Bułgarię i Bizancjum wojna.

Zarówno w listach Mikołaja Mistyka, jak i Teodora Dafnopatesa pobrzmiewa myśl, że wojen nie powinny prowadzić ze sobą państwa chrześcijańskie, chrześcijanie, których łączy ze sobą jedna wiara, a w przypadku Bizantyńczyków i Bułgarów jeszcze i fakt, że ci drudzy przyjęli ją od tych pierwszych $^{46}$. Po przyjęciu chrześcijaństwa przez Bułgarów Bizantyńczycy sądzili, że stanie się to podstawą pokojowych, stabilnych stosunków między tymi państwami ${ }^{47}$. Doświadczenia zmagań z Symeonem z pewnością nadwątliły tę wiarę, ale analizowani autorzy uznawali, że trzeba akcentować wątek wspólnej religii i używać argumentów o charakterze religijnym w korespondencji z Symeonem ${ }^{48}$. Czy wierzyli w skuteczność tej argumentacji, to już inna sprawa.

Obraz działań wojennych i ich skutków stanowi jedynie narzędzie, które próbuje wykorzystać patriarcha Konstantynopola, a także Teodor Dafnopates, choć ten w skromniejszy sposób, do nakłonienia Symeona do zawarcia pokoju. Jest to obraz topiczny, wypływający z chrześcijańskiego

44 Na ten temat szerzej: Kh. Trendafilov, Mladostta na car Simeon, Sofija 2010, s. 27-38; Leszka, Symeon I Wielki, s. 34-38. Nie można wykluczyć, że wiedzę o monastycznym etapie w życiu Symeona miał Roman Lekapen i jego sekretarz i stąd wymienienie mnichów jako ofiar Symeona. Jednak ze względu na lakoniczność i topiczność fragmentu listu 5 poświęconego tej kwestii należy zachować wstrzemięźliwość w sądach.

45 Nicolaus I Constantinopolitanus patriarcha, Epistula 14: „panuje nad namiętnościami, powstrzymując się od rozkoszy podniebienia nie mniej niż ci, którzy [pędzą ascetyczne] życie w górach, nie skosztował wina i w niczym nie odróżnia się od tych, którzy przyrzekli żyć poza tym światem [...]”, tł. A. Brzóstkowska, s. 322.

46 Szerzej: Malakhov, Koncepcija, s. 23. Nader wymowne w tej kwestii wydaje się być stwierdzenie Teodora Dafnopatesa: „Wiedz mój duchowy bracie, że nie zostaliśmy stworzeni przez Boga dla zabijania się nawzajem" (Theodorus Daphnopates, Epistula 7 , s. 83). Por. Marinow, Wojna i pokój, s. 236-239.

47 P. Angelov, Bylgarskata srednovekovna diplomacija, Sofija 1988, s. 89; Malakhov, Koncepcija, s. 23; Chrysostomides, Byzantine Concepts, s. 94; M.J. Leszka, Stracone złudzenia. Religijny kontekst stosunków bizantyńsko-butgarskich w latach 863-927, w: Religijna mozaika Bałkanów, red. M. Walczak-Mikołajczakowa, Gniezno 2008, s. 32-39.

48 Na temat religijnych argumentów w korespondencji z Symeonem, zob. P. Angelov, Religiozni argumenti v korespondencijata na car Simeon, w: Simeonova Bylgarija v istorijata na evropejjskija jugoiztok: 1100 godini ot bitkata pri Akheloj, I, red. A. NikolovN. Kynev, Sofija 2018, s. 206-213. 
stosunku do wojny, ale dobór niektórych elementów wydaje się być konsekwencją znajomości biografii adresata i przeto nabiera osobistego wymiaru.

\section{Zakończenie wojny - cena pokoju}

Pokójjestwartościąnadrzędną. On bowiem,jakpisałTeodorDafnopates, jest warunkiem harmonijnego związku człowieka z Chrystusem ${ }^{49}$. Pokój niesie za sobą jedynie dobro ${ }^{50}$ i podoba się Bogu. Trzeba za wszelką cenę dążyć do jego zawarcia. Jeśli w tym celu trzeba poczynić ustępstwa, to należy to robić. Zawarcie pokoju może wiązać się, jak pisał Mikolaj Mistyk, z wypłatą trybutu - przekazaniem złota, srebra czy innych kosztowności ${ }^{51}$. Podobnie twierdzi Dafnopates ${ }^{52}$. Jest to zjawisko całkowicie naturalne. Zdarzało się w przeszłości wielokrotnie. Nawet jeśli Bizantyńczycy byli stroną, która zobowiązywała się do wypłacania trybutu, to nie było w tym nic niegodnego. Mikołaj Mistyk pisze, że dla pokoju można nawet poświęcić część swego terytorium ${ }^{53}$. Teodor Dafnopates jednak formułuje w tej kwestii inny pogląd. Twierdzi, że nie można przekazywać ziemi, którą Bóg nam powierzył, ,narodom dzikim i krwi żądnym”. To byłoby wbrew boskiej woli i takie posunięcie należy uznać nie tyle za racjonalne działanie, nie za ustępstwo, a za przestępstwo ${ }^{54}$.

Mikołaj Mistyk w porównaniu z Dafnopatesem stawia granicę dalej. Widzi ją dopiero w utracie suwerenności. Takiej ceny za pokój zapłacić nie można ${ }^{55}$. Patriarcha Konstantynopola powraca stosunkowo często do

49 Theodorus Daphnopates, Epistula 6. Por. Theodorus Daphnopates, Epistula 4 (w liście do emira Egiptu pisał, że Bóg jest pokojem, Bóg nienawidzi wojny, która niesie za sobą śmiertelne ofiar). Por. Marinow, Wojna i pokój, s. 224, 236-243.

$50 \mathrm{~Np}$. Nicolaus I Constantinopolitanus patriarcha, Epistula 16; 17; 23. Por. także: Theodorus Daphnopates, Epistula 4 (pokój wzbogaca ludzi, wojna niszczy).

51 Nicolaus I Constantinopolitanus patriarcha, Epistula 25; 27.

52 Teodor Dafnopates dwukrotnie pisze (Theodorus Daphnopates, Epistula 5; 7), co Bizantyńczycy uczynili, by zachować pokój, wskazując na akcje dyplomatyczną, w tym zorganizowanie bezpośredniego spotkania Romana Lekapena z Symeonem, przekazanie darów i gotowość na dalsze.

53 Nicolaus I Constantinopolitanus patriarcha, Epistula 27. Por. L. Simeonova, Power in Nicholas Mysticus' Letters to Symeon of Bulgaria (Notes on the political vocabulary of a tenth century Byzantine statesman), „Byzantinoslavica” 54 (1993) s. 93.

54 Theodorus Daphnopates, Epistula 5, tł. A. Brzóstkowska, s. 165-166.

55 Na temat terminów używanych przez Mikołaja Mistyka na określenie suwerenności, patrz: Simeonova, Power in Nicholas Mysticus'Letters, s. 90-93. 
tej myśli. Najlapidarniej, a jednocześnie najcelniej wyraził ją w liście 25: „Dążenie zaś do zwycięstwa to dążenie do całkowitego zagarnięcia cudzej władzy, jak też do tego, by siebie uczynić panem całego narodu i państwa, a to jest rzecz najstraszniejsza i wobec cesarstwa Romajów całkowicie niemożliwa"56.

Takie jednoznaczne i stanowcze stanowisko nie dziwi. Jest to przecież oczywistość. Pamiętać jednak należy, że w tym konkretnym przypadku nie stanowi ono jedynie retorycznej emfazy czy odwołania do imponderabiliów, ale stanowi odpowiedź na roszczenia bułgarskiego władcy, który przecież nadał sobie tytuł bazyleusa Romajów oraz Bułgarów i który odmawiał praw do tronu Romanowi Lekapenowi, nazywając go uzurpatorem ${ }^{57}$. W tej sytuacji patriarcha uznał za konieczne uświadomić Symeonowi tę oczywistość i w sposób niebudzący żadnych wątpliwości wskazać granicę, której przekroczenie jest niemożliwe, nawet za cenę dalszej krwawej wojny. Biskup Konstantynopola ostrzegał bułgarskiego władcę, że w takiej sytuacji przeciw niemu staną wszyscy zdolni do noszenia broni Romajowie ${ }^{58}$, a także zostanie wykorzystana pomoc pogan-barbarzyńców. Ten ostatni wątek dotykał konstantynopolitańskiego pasterza. Poganie przelaliby chrześcijańską krew, co samo w sobie było tragiczne, a stałoby się to przecież z inicjatywy samych wyznawców Chrystusa ${ }^{59}$. Mimo tego nawet taki krok należy podjąć, aby zachować suwerenność ${ }^{60}$.

\section{Wnioski}

Listy Mikołaja Mistyka i Teodora Dafnopatesa do Symeona obracają się wokół spraw wojny i pokoju. Stosunek do wojny, który można w nich odnaleźć, jest jednak schematyczny. Wojna jest złem i wiąże się z prze-

56 Nicolaus I Constantinopolitanus patriarcha, Epistula 25, tł. A. Brzóstowska, s. 350. Zob. również: Nicolaus I Constantinopolitanus patriarcha, Epistula 19; 27.

57 Leszka, Symeon I Wielki, s. 241-243.

58 Nicolaus I Constantinopolitanus patriarcha, Epistula 31.

59 Nicolaus I Constantinopolitanus patriarcha, Epistula 23; Wozniak, The Metaphysics of Byzantine Diplomacy, s. 293.

60 Z problemem użycia pogan przeciw chrześcijańskim Bułgarom skonfrontował się Leon VI w dobie wojny z lat 894-896 w traktacie militarnym Taktyki. Cesarz, mając świadomość, że przelew chrześcijańskiej krwi jest niewątpliwie czymś złym, doszedł do ciekawego wniosku: dzięki temu, że Boża Opatrzność skierowała przeciw Bułgarom, którzy złamali pokój, pogańskich sojuszników Bizancjum, Romajowie nie splamili rąk krwią swych braci w wierze. Zob. Leo VI, Tactica XVIII 42. 
lewem krwi, okrucieństwami i grabieżą. Szczególnego znaczenia w tym niezbyt wyraźnym szkicu nabierają odwołania do cierpień, które dotykają mnichów i mniszki. Ten wątek, jak się wydaje, był eksploatowany ze względu na monastyczny etap w życiu bułgarskiego władcy. Odwołując się do osobistych sentymentów Symeona, chciano wstrząsnąć nim i w końcu przekonać do zawarcia pokoju.

Dla Mikołaja Mistyka i Teodora Dafnopatesa pokój jest dobrem najwyższym i w celu jego zachowania można iść na znaczne ustępstwa. Istnieje jednak granica, której nawet dla zachowania pokoju przekraczać nie należy. Tą granicą w przypadku Mikołaja Mistyka jest zachowanie własnej suwerenności. Teodor Dafnopates wskazuje, że tę granicę trzeba postawić $\mathrm{w}$ innym miejscu. Musi nią być zachowanie integralności terytorialnej państwa Romajów. Wydaje się, że różnicę, która uwidoczniła się w poglądach Mikołaja Mistyka i Teodora Dafnopatesa, należy tłumaczyć, przynajmniej w jakimś stopniu, charakterem ich korespondencji. Listy Mikołaja Mistyka, w których mówił on o gotowości ustępstw terytorialnych jako ceny pokoju, powstały w czasie, kiedy patriarcha nie pełnił roli przewodniczącego rady regencyjnej i nie miał wpływu na cesarską politykę. Nie miały one tej wagi, co listy pisane przez Teodora, a sygnowane przez cesarza Romana Lekapena, które stanowiły oficjalne stanowisko Bizancjum w negocjacjach z Symeonem. Twarda postawa Romana Lekapena w sprawie cesji terytorialnych na rzecz Bułgarii przy jednoczesnej gotowości do zwiększenia finansowej zapłaty za pokój jasno określała warunki dalszych negocjacji. Roman Lekapen piórem Teodora Dafnopatesa uzasadniał też myśl, że jakiekolwiek wysiłki jednej i drugiej strony na rzecz pokoju mogą być bezcelowe, jeśli taka będzie wola Boga: ,że gdybyś nawet chciał zawrzeć pokój, to nie zdołasz - tak Bóg utwardził twoje serce, aby na tobie dowieść swej mocy" ${ }^{61}$.

\section{Byzantine Intellectuals on War and Peace (Nicholas Mystikos and Theodore Daphnopates)}

(summary)

The letters of Nicholas Mystikos and Theodore Daphnopates/Romanos Lekapenos to Simeon, the ruler of Bulgaria, revolve around matters of war and peace. The attitude to the war that can be found in them is, however, formulaic. The war is evil and tied to bloodshed, cruelty and plunder. In this vague overview the references to the suffering of monks

61 Theodorus Daphnopates, Epistula 5, tł. A. Brzóstkowska, s. 168. 
and nuns play a significant role. This seems to have been brought up due to the monastic episode in the life of the Bulgarian ruler. Referencing personal sentiments of Simeon were meant to shake him up and eventually convince to settle for the peace. For Nicholas Mystikos and Theodore Daphnopates/Romanos Lekapenos peace is the greatest good and in order to preserve it many concessions can be justified. There is however a boundary that should not be crossed. For Nicholas Mystikos it is the retention of sovereignty. This view is obviously shared by Theodore Daphnopates, however, he points out that the boundary should be moved further and be concerned with the preservation of the territorial integrity of the Roman state.

Keywords: Nicholas Mystikos; Theodore Daphnopates; Romanos Lekapenos; Symeon I the Great; Byzantium

\section{Bizantyńscy intelektualiści o wojnie i pokoju (Mikołaj Mistyk i Teodor Dafnopates)}

(streszczenie)

Listy Mikołaja Mistyka i Teodora Dafnopatesa/Romana Lekapena do Symeona, władcy bułgarskiego obracają się wokół spraw wojny i pokoju. Stosunek do wojny, który można w nich odnaleźć, jest jednak schematyczny. Wojna jest złem i wiąże się z przelewem krwi, okrucieństwami i grabieżą. Szczególnego znaczenia w tym niezbyt wyraźnym szkicu nabierają odwołania do cierpień, które dotykają mnichów i mniszki. Ten wątek, jak się wydaje, był eksploatowany ze względu na monastyczny etap w życiu bułgarskiego władcy. Odwołując się do osobistych sentymentów Symeona, chciano wstrząsnąć nim i w końcu przekonać do zawarcia pokoju. Dla Mikołaja Mistyka i Teodora Dafnopatesa/Romana Lekapena pokój jest dobrem najwyższym i w celu jego zachowania można iść na znaczne ustępstwa. Istnieje jednak granica, której przekraczać nie należy. Tą granicą w przypadku Mikołaja Mistyka jest zachowanie suwerenności. Teodor Dafnopates wskazuje, że tę granicę trzeba postawić w innym miejscu. Musi nią być zachowanie integralności terytorialnej państwa Romajów.

Słowa kluczowe: Mikołaj Mistyk: Teodor Dafnopates; Roman Lekapen; Symeon I Wielki; Bizancjum

\section{Bibliografia}

\section{Źródła}

Leo VI, Tactica: Leonis VI Tactica, ed. i tł. G.T. Dennis, CFHB (Series Washingtoniensis) 49, Washington 2010.

Nicolaus I Constantinopolitanus patriarcha, Epistula, Nicolai I Constantinopolitani patriarchae Epistulae, ed. tł. R.J.H. Jenkins - L.G. Westerink, CFHB 6, Washington 
1973, tł. A. Brzóstkowska, Mikołaj Mistyk, Testimonia najdawniejszych dziejów Stowian, Seria grecka 3, wyd. A. Brzóstkowska - W. Swoboda, Warszawa 1995, s. 294-376.

Theodorus Daphnopathes, Epistula: Théodore Daphnopatès, Corréspondance, ed., tł. J. Darrouzès - L.G. Westerink, Paris 978, tł. A. Brzóstkowska, Teodor Dafnopates, Testimonia najdawniejszych dziejów Słowian, Seria grecka 4: Pisarze z VIII-XII wieku, wyd. A. Brzóstkowska - W. Swoboda, Warszawa 1997, s. 160-180.

\section{Opracowania}

Aleksandrov E., Diplomaticheskaja perepiska carja Simeona s imperatorom Romanom Lakapinom, „Palaeobulgarica” 14/2 (1990) s. 16-22.

Angelov D., Metody vizantijjskoj diplomatii v otnoshenijakh s Bolgariejj po danym pisem konstantinopolskogo patiarkha Nikolaja Mistika, „Voprosy Istorii Slavjan” 1 (1963) s. 60-69.

Angelov P., Bylgarskata srednovekovna diplomacija, Sofija 1988.

Angelov P., Religiozni argumenti v korespondencijata na car Simeon, w: Simeonova B'lgarija v istorijata na evropejjskija jugoiztok: 1100 godini ot bitkata pri Akheloj, I, red. A. Nikolov - N. Kynev, Sofija 2018, s. 206-213.

Antonopoulou T., A Textual Source and Its Implications: On Theodore Daphnopates Sermon On the Birth of John the Baptist, „Byzantion” 81 (2011) s. 9-17.

Bozhilov I., Car Simeon Veliki: zlatnijat vek na Srednovekovna B”lgarija, Sofija 1983. Chernoglazov D. Beobachtungen zu den Briefen des Theodoros Daphnopates. Neue Tendenzen in der byzantinischen Literatur des zehnten Jahrhunderts, ByZ 106 (2013) s. 623-644.

Chrysostomides J., Byzantine Concepts of War and Peace, w: War, Peace and World Orders in European History, ed. A.V. Hartmann - B. Heuser, London - New York 2001, s. 91-101.

Dagron G., Kościół i państwo (połowa IX-koniec X wieku), w: Historia chrześcijaństwa. Religia. Kultura. Polityka, t. 4: Biskupi, mnisi i cesarze 610-1054, tł. M. Żurowska et al., red. G. Dagron - P. Riché - A. Vauchez, Warszawa 1999, s. 163-169.

Haldon J., Warfare, State and Society in the Byzantine World, London 1999.

Howard-Johnston J., A short piece of narrative history: war and diplomacy in the Balkans, winter 921/2-spring 924, w: Byzantine Style, Religion and Civilization. In Honour of Sir Steven Runciman, ed. E. Jeffreys, Cambridge 2006, s. 340-360.

Jenkins R.J.H., A Note on the Patriarch Nicholas Mysticus, w: R.J.H. Jenkins, Studies on Byzantine History of the $9^{\text {th }}$ and $10^{\text {th }}$ Centuries, London 1970, s. 145-147.

Kapsalykova K.R., Predstavlenie o vojjne $i$ armii v Vizantii (seredina IX-seredina XI), Ekaterinoburg 2017 (niepublikowana praca doktorska).

Karlin-Hayter P., Le synode à Constantinople de 886 à 912 et le rôle de Nicolas le Mystique dans l'affaire de la tétragamie, JÖB 19 (1970) s. 59-101.

Kazhdan A., A History of Byzantine Literature (850-1000), ed. A.C. Angelidi, Athens 2006. 
Kazhdan A., Daphnopates, Theodore, w: The Oxford Dictionary of Byzantium, ed. A. Kazhdan, New York - Oxford 1991, s. 588.

Leszka M.J, Mikołaj Mistyk, patriarcha Konstantynopola w świetle korespondencji z Symeonem, władca Butgarii, „Balcanica Posnaniensia” 18 (2011) s. 23-33.

Leszka M.J., Obraz wojny w Listach Mikołaja Mistyka do Symeona, władcy bułgarskiego, „Slavia Antiqua” 47 (2006) s. 9-16.

Leszka M.J., Stracone złudzenia. Religijny kontekst stosunków bizantyńsko-bułgarskich w latach 863-927, w: Religijna mozaika Bałkanów, red. M. Walczak-Mikołajczakowa, Gniezno 2008, s. 32-39.

Leszka M.J., Symeon I Wielki a Bizancjum. Z dziejów stosunków bułgarsko-bizantyńskich w latach 893-927, Byzantina Lodziensia 15, Łódź 2013.

Ljubarskijj J.N., Zamechanija o Nikolae Mistike v svjazi s izdaniem ego sochinenijj, w: J.N. Ljubarskijj, Vizantijjskie istoriki i pisateli (sbornikstatejj), Sankt-Peterburg1999, s. 55-67.

Malakhov S.N., Koncepcija mira v politicheskojj ideologii Vizantii pervojj poloviny Xv. Nikolaj Mistik Feodor Dafnopat, „Antichnaja Drevnost i Srednie Veka” 27 (1995) s. 19-31.

Marinow K., Wojna i pokój w Domu Bożym. Uwagi na temat ideologicznej wymowy dwóch motywów w mowie Na pokój z Bułgarami, w: Piotr I Święty, car bułgarski (ok. 912-969). Maria Lekapena, caryca butgarska (ok. 912-?963), red. Z.A. Brzozowska - M.J. Leszka - K. Marinow, Kraków 2018, s. 219-244.

Mokhov A.S. - Kapsalykova K.R., Obrazy vojjny v vizantijjskojj istoricheskoj literature Xv.:Feodor Dafnopat, ,Nauchnye vedomosti Belgorodskogo gosudarstennogo universiteta. SerijaIstorija. Politologija" 36 (2015) s. 44-49.

Peace and War in Byzantium. Essays in Honor of George T. Dennis, S.J., ed. T.S. Miller - J. Nesbit, Washington 1995.

Simeonova L., Power in Nicholas Mysticus'Letters to Symeon of Bulgaria (Notes on the political vocabulary of a tenth century Byzantine statesman), „Byzantinoslavica” 54 (1993) s. 89-94.

Sjuzjumov M., Ob istoricheskom trude Feodora Dafnopata, „Vizantijjskoe obozrenie” 2 (1916) s. 295-302.

Stanković V., Carigradski patrijarsi i carevi makedonske dinastije, Beograd 2003.

Strässle P.M., Krieg und Frieden in Byzanz, „Byzantion” 74 (2004) s. 110-129.

Tougher S., The Reign of Leo VI (886-912). Politics and People, Leiden - New York Köln 1997.

Trendafilov Kh., Mladostta na car Simeon, Sofija 2010.

Wozniak F.E., The Metaphysics of Byzantine Diplomacy in the Relations of the Byzantines and Bulgarians 880's - 920's, GOTR 21 (1976) s. 289-297.

Zlatarski V.N., Pismata na vizantijjski imperator Romana Lakapena do b"garskija car Simeon, ,Sbornik narodni umotvorenija, nauka i knizhnina” 13 (1896) s. 282-322. 